\title{
Shallow gas features and distribution in the Patos Lagoon: a coastal trap for gas-generator sediments
}

\author{
Jair WESCHENFELDER \& Iran Carlos Stalliviere CORRÊA
}

Centro de Estudos de Geologia Costeira e Oceânica \& Programa de Pós-Graduação em Geociências, Instituto de Geociências, Universidade Federal do Rio Grande do Sul. Av. Bento Gonçalves, 9.500, CEP 91.540-000, Porto Alegre, RS, Brasil (jair.weschenfelder@ufrgs.br, iran.correa@ufrgs.br).

Weschenfelder, J. \& Corrêa, I.C.S. 2018. Shallow gas features and distribution in the Patos Lagoon: a coastal trap for gas-generator sediments. Pesquisas em Geociências, 45: e0683.

DOI: https://doi.org/10.22456/1807-9806.91385

\begin{abstract}
Gas-charged sediments are very common in coastal environments worldwide, and their occurrence is usually clearly revealed as acoustic anomalies by a number of different seismic tools at differing scales and resolutions. This paper presents examples of gas-related acoustic anomalies in high resolution sub-bottom profiles (SBP) from the Patos Lagoon, Southern Brazil. The echograms show acoustic gas-related anomalies, which can present distinctive morphology for sediment-trapped gas, leaking or free gas in the water column. The paleo-topographic depressions filled with gas-charged sediments are related to former drainage systems developed in the coast in response to Quaternary sea level up and down events. Hence, such shallow gas occurrences seem to be controlled by the previous environmental configuration, the transgressive infilling arrangement of the basin, and the hydrodynamic conditions. Since the establishment of the present configuration, following sea level highstand of the Holocene, the Patos Lagoon interior seems to behave as a coastal trap for fine-grained, organic-rich gas-generator sediments, bordered by coarser gas-free sediments.

Keywords. geoacoustics, gassy sediments, coastal evolution, Brazil.
\end{abstract}

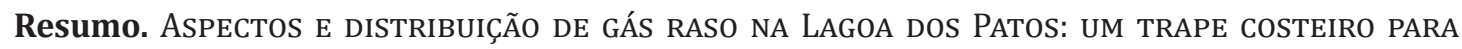
SEDIMENTOS GERADORES DE GÁs. Sedimentos gasosos são muito comuns nos ambientes costeiros em todo o mundo e suas ocorrências são claramente reveladas como anomalias acústicas por diversas ferramentas sísmicas, em diferentes escalas e resoluções. Este artigo apresenta exemplos de anomalias acústicas relacionadas ao gás, em perfis sísmicos (SBP) de alta resolução da Lagoa dos Patos, Sul do Brasil. Os ecogramas mostram anomalias acústicas devidas ao gás, as quais podem apresentar uma morfologia distinta para gás aprisionado no sedimento, percolação ou gás livre na coluna de água. As depressões topográficas pretéritas preenchidas com sedimentos gasosos são relacionadas aos antigos sistemas de drenagem, desenvolvidos na região costeira devido às oscilações do nível do mar durante o Quaternário. Assim, essas ocorrências de gás raso parecem ser controladas pela configuração paleoambiental, arranjo de preenchimento da bacia de sedimentação e condições hidrodinâmicas. Desde o estabelecimento da configuração atual, após o período de nível do mar alto do Holoceno, o interior da lagoa de Patos comporta-se como uma armadilha costeira para sedimentos finos, ricos em matéria orgânica e propícios a formação de gás, margeado por sedimentos mais grossos e sem gás.

Palavras-chave. geoacústica, sedimentos gasosos, evolução costeira, Brasil. 


\section{Introduction}

Gas in sediments can be found in various types of coastal environments, where normally the ideal conditions for biogenic gas formation due to high biological productivity occur. Gas-charged sediments is a common phenomenon worldwide and so have been related in the most coastal environments as shallow or enclosed seas and shelves (Emeis et al., 2004; Terra et al., 2014), lakes (Lafferty et al., 2006), bays (Baptista Neto et al., 1996; Quaresma et al., 2000; Catanzaro et al., 2004; Jensen \& Bennike, 2009; Marino et al., 2013; Aliotta et al., 2014; Klein et al., 2016), rias (Garcia-Gil et al., 2002; Diez et al., 2007; Duarte et al., 2007; Iglesias \& Garcia-Gil, 2007), deltas (Figueiredo Jr. et al., 1996), lagoons (Baptista Neto et al., 2011; Klein et al., 2016; Weschenfelder et al., 2006, 2016) and estuaries (Frazão \& Vital, 2007; Pinet et al., 2008). The gas sources and accumulation modes are closely related to the sedimentary and evolutionary processes occurring in the depositional environment (Garcia-Gil et al., 2002). Hence, the various gas reservoir and trapping sites, together with their associated types of gas accumulation and environmental settings provide valuable clues to the evolution of coastal and shallow marine environments (Garcia-Gil et al., 2002).

Gassy sediments are normally detected by geoacoustic surveying due to the change of sound wave speed caused by the gas content. The higher the speed gradient, the stronger will be the echo due the acoustic impedance variation between media with and without gas. The echo intensity recorded in the echogram reflects the concentration of gas bubbles interspersed in the medium (Judd \& Hovland, 1992; Aliotta et al., 2009). In acoustic seismic profiles the gas-related structures display various forms like blankets, curtains, columns, turbidity zones, pinnacles, intra-sedimentary plumes and others seismic signature (Garcia-Gil et al., 2002; Frazão \& Vital, 2007). The leaking of gas is also common and can occur as plumes, pockmarks and other features (Garcia-Gil et al., 2002; Frazão \& Vital, 2007).

The occurrence of gassy sediments, the mechanics of gas trapping and the geomorphic and sedimentological settings of such phenomena de- serve to be more intensely explored, taking into account the present environmental concerns. Gas is normally slowly released to the atmosphere and the total methane contribution of such a source to the global budget is poorly constrained (Judd, 2004). Further, gas-charged sediments may represent risks to engineering works and terrain stability (Premchitt et al., 1992).

This paper addresses the various gas features found in the Patos Lagoon, in Southern Brazil. It presents seismic records of shallow gas-induced acoustic anomalies in lagoon sediments, adding to the examples presented by Weschenfelder et al. (2006) as well as improving such discussion on gas examples and features, spatial distribution, and respective depositional environments.

\section{Area, materials and methods}

\subsection{Study area}

Southern Brazil coastal plain and continental shelf configuration mainly results from Quaternary sea level changes, whose multiple cycles have affected the sedimentary systems along the coast. Likewise, seismostratigraphic studies have revealed that the Rio Grande do Sul (RS) coastal plain and shelf were deeply dissected by rivers before formation of the present landscape, with streams cutting deep valleys to accommodate base level fall and long periods of relative sea level lowstands (Weschenfelder et al., 2014). Hence, before drowning by transgression, the shelf surface was subaerial and subject to severe erosion and fluvial incision. Infilling of these coastal incision occurred during the subsequent transgressive and highstand sea level periods (Weschenfelder et al., 2014; Santos-Fischer, 2016). Upstream such paleodrainage incisions cut mainly into the coastal prism deposited during previous sea level highstand events. Downstream the paleodrainage paths extend oceanwards to the shelf edge by means of morphostructural data (Corrêa et al., 2007; Weschenfelder et al., 2014).

The RS shelf is characterized by a smooth morphology with very low gradient (1.3-1.4 m/ $\mathrm{km}$ ) and an average width of $125 \mathrm{~km}$ (Fig. 1). The northern section is narrow and homogeneous; the 
southern is wider and gently dissected. In the south area, the usually smooth morphology is interrupted by sand bodies, sand waves and elongated bioclastic deposits which have been interpreted as paleoshoreline indicators (Corrêa, 1996). Marine terraces with steeper slopes throughout the shelf have been interpreted as a relic of periods of stabilization in the sea level during the Holocene transgressive event (Corrêa, 1996).

Coastal plain of the RS is a wide lowland covering around 33,000 $\mathrm{km} 2$, bordering highlands to the west and a wide and very gentle gradient continental shelf to the east. Four lagoon-barrier type depositional systems, related to transgressive-regressive events of the Quaternary, have been recognized on it (Villwock \& Tomazelli, 1995; Tomazelli \& Villwock, 2000). A correlation between the sea level lowstands and major troughs of the oxygen isotope curve has been indicated by Weschenfelder et al. $(2008,2014)$, which should confirm the correlation between sea level position and climate changes.
Patos Lagoon (Fig. 1) is the most remarkable physiographic feature of the RS coast. It is a large warm-temperate lagoon, covering an area of $10,000 \mathrm{~km}^{2}$, with a NE-SW oriented length of 240 $\mathrm{km}$, an average width of $40 \mathrm{~km}$ and a depth of $6 \mathrm{~m}$. Bottom sediments comprise a fringe of marginal sands (60\% in area) and internal muddy sediments. Depths between 5 and $6 \mathrm{~m}$ separate both areas. The lagoon bottom and margins are influenced by local waves, which may reach up to $1.6 \mathrm{~m}$ high (Toldo Jr. et al., 2000). The rivers of the Guaíba Hydrographic Basin (Jacuí, Sinos, Taquari rivers), with an area of $\sim 200,000 \mathrm{~km}^{2}$, and Camaquã River Basin with an area of $24,000 \mathrm{~km}^{2}$, drain into the NW and SW lagoon margin respectively (Marques, 2005). The mean annual freshwater discharge of the both basins into the Patos Lagoon is 2,400 $\mathrm{m}^{3} / \mathrm{s}$ (Marques \& Möller, 2008), which influx contributes to the circulation patterns, mixing and exchanging process, and sediment transport (Marques, 2012). The mean annual freshwater discharge of the Camaquã River is $\sim 400 \mathrm{~m}^{3} / \mathrm{s}$ (Vaz

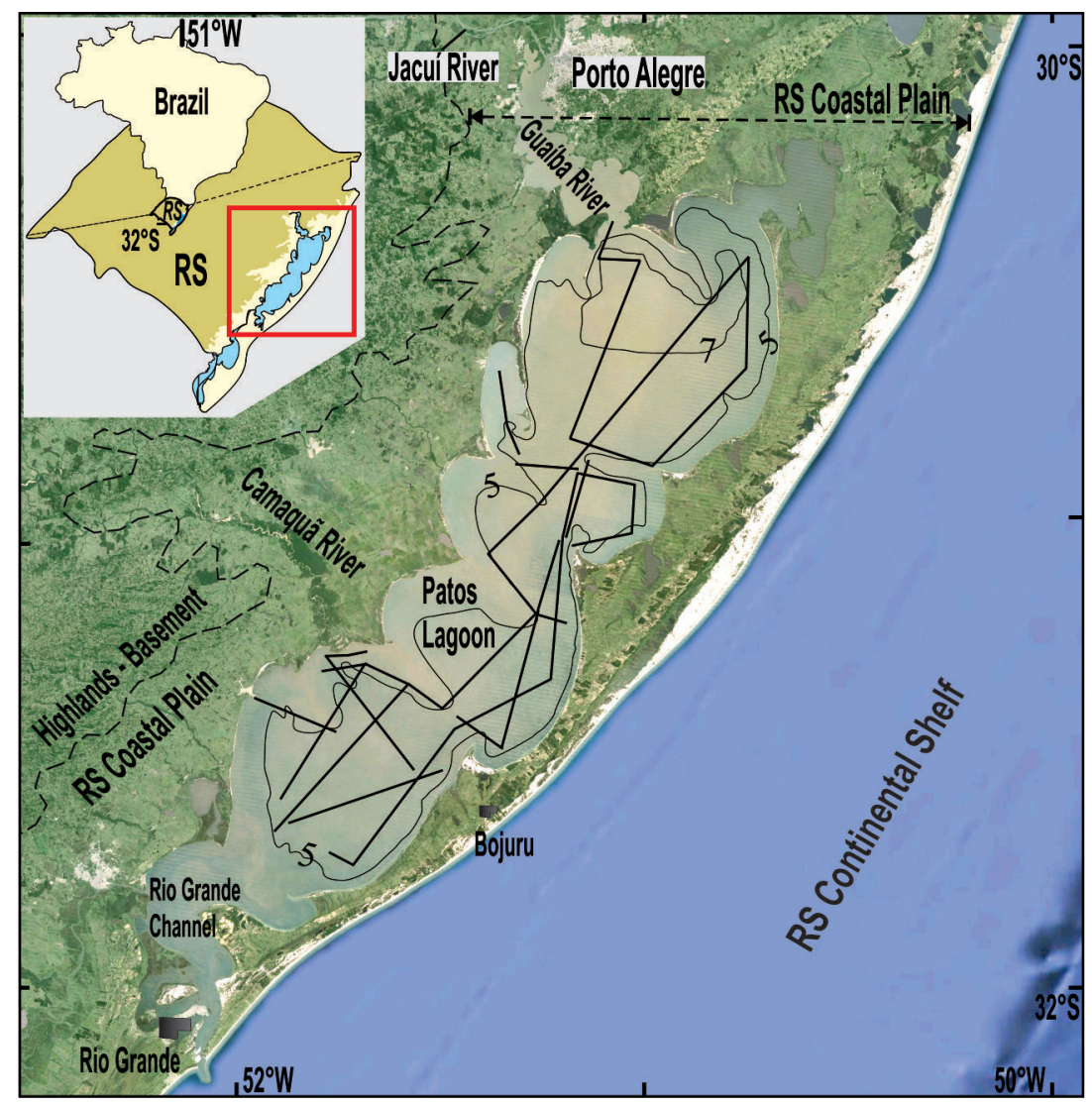

Figure 1. Study area (Patos Lagoon) with the location of the seismic profiles analyzed. The box represents the area shown in the Google Earth (GE) image.

Figura 1. Área de estudo (Lagoa dos Patos) com a posição dos perfis sísmicos estudados. O retângulo indica a área na imagem Google Earth (GE). 
et al., 2006), and its sediment load influx is also constructing an intralagoonal delta in the western lagoon margin. The freshwater influx peak into de Patos Lagoon reaches values up to $16,000 \mathrm{~m}^{3} / \mathrm{s}$, according to Marques (2005); also, Calliari et al. (2009) reported that peak flow rates exceeding $20,000 \mathrm{~m}^{3} / \mathrm{s}$ have been reported during periods of El Ninõ. According to Andrade Neto et al. (2012) the mean annual suspended solid discharge from the Guaíba Hydrographic Basin into the lagoon corresponds to 1.1 million ton/year with a yearly sediment supply rate of $0.11 \mathrm{~kg} / \mathrm{m}^{2}$.

A comprehensive study of the fine grain sediment transport and deposition of the Patos Lagoon, the Patos Estuary and the adjacent oceanic beach sedimentary system is presented by Calliari et al. (2009). According to these authors, extensive mud deposits on the shelf adjacent to the Patos Lagoon estuary indicate the Lagoon as the potential source of fine sediments to the coastal sedimentary system. Hence, the Patos Lagoon receives a significant river discharge (solid and liquid) and leads it to the Atlantic Ocean through a single inlet, the Rio Grande estuarine channel. The lagoon environment is protected from the nearby high-energy wave-dominated ocean by a large coastal sandy barrier, where the microtidal amplitude open ocean tidal oscillation averages up to $40 \mathrm{~cm}$.

\subsection{Methods}

Gas as a pervasive feature in the sediments cause strong acoustic anomalies in echograms and so can be surveyed by a number of different seismic tools at differing scales and resolutions. The gas accumulation signatures and distribution in the Patos Lagoon have been studied with acoustic tool, high resolution, seismic records (3.5 and 7 $\mathrm{kHz}$ ).

The $3.5 \mathrm{kHz}$ echograms, resulting in a vertical resolution $\sim 10 \mathrm{~cm}$, were obtained throughout the lagoon employing a Geopulse sub-bottom profiling system (from GeoAcoustics ${ }^{\mathrm{TM}}$ ) with acquisition and processing SonarWiz ${ }^{\mathrm{TM}}$ software (from Chesapeake Technology). The south and central area of the lagoon was surveyed, in a previous work, using a Raytheon shallow seismic system (details in Toldo Jr. et al., 2000). The resulting $7 \mathrm{kHz}$ echograms present a vertical resolution of $\sim 20 \mathrm{~cm}$.

To identify the seismic architectural elements associated with the gas features the analysis of the echograms was based on the general concepts established by the seismic stratigraphy approach (Mitchum Jr. et al., 1977). To evaluate the thickness of the sedimentary units a sound velocity in sediments of $1,650 \mathrm{~m} / \mathrm{s}$ is assumed by converting the sound wave travel period into meters (Jones, 1999).

A synopsis of various terms used to describe and classify the shallow gas occurrences in coastal environments was presented by Weschenfelder et al. (2016), whose gas terminology is used in this paper to describe and classify the gas features observed in the echograms from the Patos Lagoon.

\section{Results}

Seismic responses due gassy sediments reflect the gas amount in the medium, since concentrations are well detected by seismo-acoustic surveying due to the contrasting acoustic impedance between gassy and gas-free sites. The acoustic turbidity is a phenomenon caused by diffusion of acoustic wave energy due to the dissemination of gas bubbles interspersed in the sediments (Hart \& Hamilton, 1993). Most of the common signatures of gas-charged sediments have been recognized in coastal sediments (Weschenfelder et al., 2016) and some of them occur also in the Patos Lagoon.

This study focuses on the identification and characterization of the gas features visualized in echograms from the Patos Lagoon. They are visualized in the seismic records as anomalous reflection caused by gases interspersed in the sediments or free gases in the water column. The distribution of gas-charged sediments in the lagoon, encompassing the gas feature types, was mapped and presented hereafter.

\subsection{Gas features in seismic records from Patos La- goon}

Seismic data revealed anomalous acoustic configurations that have been attributed as typical for sediments charged with gas in the Patos Lagoon (Figs. 2A, 3A and 4A). Overall, gassy sediments in 
the Patos Lagoon are concentrated mainly in the deeper areas, where muddy sediments occur, as opposed to the sandy margins (see Fig. 5).

The gas curtain feature can span laterally up to several kilometers in the echograms from the Patos Lagoon sub-bottom (Fig. 2). The top reflector of gas curtains is sometimes abruptly interrupted, forming gaps without significant acoustic anomalies or showing the so called "acoustic windows" (Fig. 2D, E). Occurring in most lagoon areas, acoustic windows occur along the seismic profiles enabling the lateral continuity of the seismo-depositional architectural elements and the internal structure of the seismic and sedimentary units to be clearly established (Weschenfelder et al., 2006).

The lateral extent of the acoustic turbid zones can also span up to several kilometers in the Patos lagoon records (Fig. 2E). The top of these gas accumulations is diffuse and eventually reaching the lagoon bottom where sometimes leaks gas into the water column (Fig. 2B, C). When the gas is located at the floor (or at least close enough to the floor that the resolution of the seismic data does not allow the correct definition of its position) it occurs as an acoustic blanking feature (Fig. 2B, C) (Weschenfelder et al., 2006).

Gas curtains occur mainly in the innermost areas of the lagoon (Fig. 3), associated with topo-
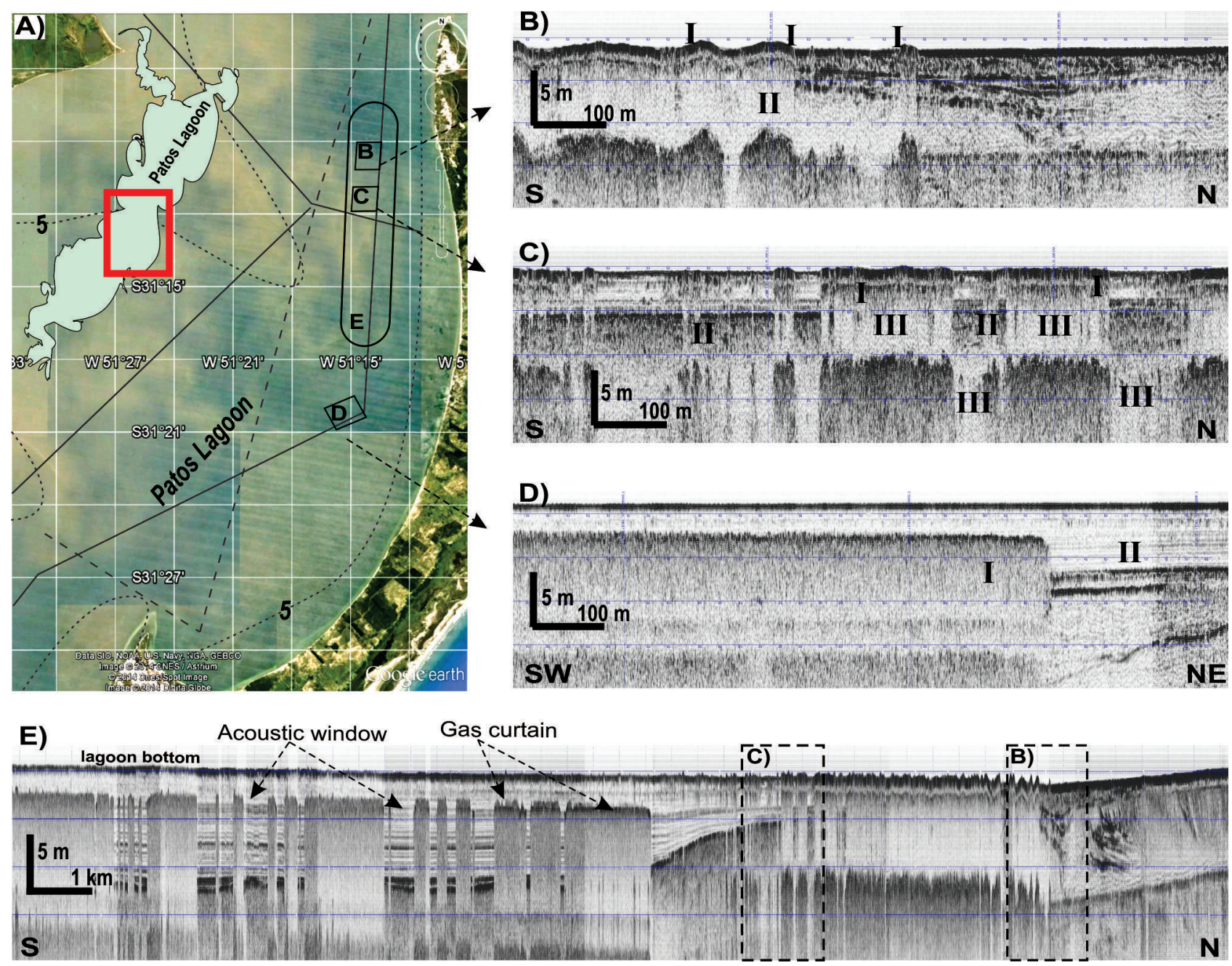

Figure 2. Gas-related acoustic anomalies in echograms from the central Patos Lagoon. A) Positions of seismic lines of 7 (dashed lines) and $3.5 \mathrm{kHz}$ are shown in the GE image (box); B) Bottom disturbation (I) and acoustic blanking (II); C) Gas (I-II), acoustic blanking (III) hiding stratigraphic reflectors; D) Transition of gas curtain (I) to gas free-zone (II); E) Anomalies affecting the reflectors and the lagoon bottom.

Figura 2. Anomalias acústicas de gás em ecogramas da região central da Lagoa dos Patos. A) Posições das linhas sísmicas de 7 (tracejado) e 3,5 kHz são exibidas na imagem GE (retângulo); B) Perturbação do fundo (I) e "blanking" acústico (II); C) Gás (I-II), "blanking" acústico (III) mascarando os refletores estratigráficos; D) Transição de cortinas de gás (I) para zonas sem gás (II); E) Anomalias afetando os refletores e o fundo lagunar. 
graphic depressions. Gassy sediments occur commonly in paleo-topographic depressions indicated by seismo-depositional units filling a negative relief in the underlying seismic sequence, which indicate the former coastal plain topography (Fig. 3D).

Well defined gas curtains also occur in the eastern margin of the Patos Lagoon in distinct stratigraphic levels (Fig. 3C). Gas curtains and disseminated gas features are also shown in $7 \mathrm{kHz}$ seismic records from the lagoon inner parts (Fig. 3B).

In the northern sector of the Lagoon the distribution of gassy sediments, and consequently associated acoustic-related anomalies in echograms, is similar to the southern and central regions (Fig. 4). Several gas-charged sectors, in curtain and disseminated, interspersed with acoustic windows in sectors with minor quantities of gas or without gas, occur mainly in the innermost lagoon area (Fig. 4C). The occurrence of gas-charged sediments is notably common in the paleo-topographic depressions (Fig. 4B) inherited from the former coastal plain topography.

Some acoustic anomalous reflectors occur commonly in the records from the Patos Lagoon, as seen in the various examples presented in Figures 2, 3 and 4. The gas curtains, for example, are usually interspersed with acoustic windows as can be visualized in various occasions in these figures, whose windows width range from few meters to some kilometers.

Multiple reflectors due the lagoon floor sound wave reflections occur constantly in the records from the shallow water lagoon. It is also observed the gas-induced multiple reflection in some places (Fig. 2D for example), where the presence of mul-
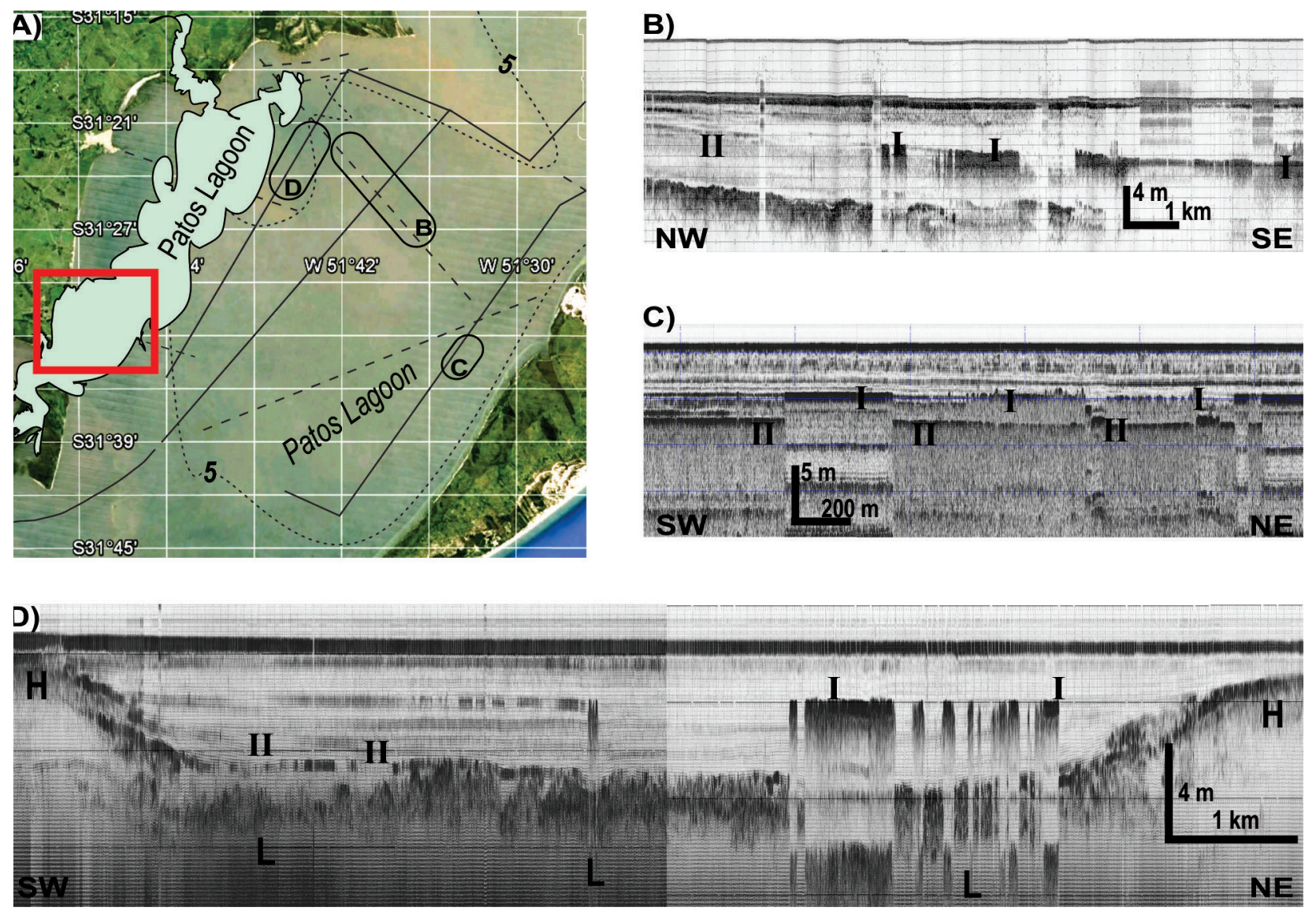

Figure 3. Gas occurrences in the southern Patos Lagoon. A) Positions of seismic lines of 7 (dashed lines) and $3.5 \mathrm{kHz}$ are shown in the GE image (box); B) Gas curtain (I) and disseminated (II) in 7 kHz records; C) Gas occurring in distinct stratigraphic levels (I-II); D) Gas in paleo-topographic lows (L- Low, H- High): curtain (I) and disseminated (II).

Figura 3. Ocorrências de gás no setor sul da Lagoa dos Patos. A) Posições das linhas sísmicas de 7 (tracejado) e 3,5 kHz são exibidas na imagem GE (retângulo); B) Cortinas de gás (I) e disseminado (II) em registros de $7 \mathrm{kHz}$; C) Gás ocorrendo em níveis estratigráficos diversos (I-II); D) Gás em paleo baixos topográficos (L-Baixo, H-Alto): cortinas (I) e disseminado (II). 

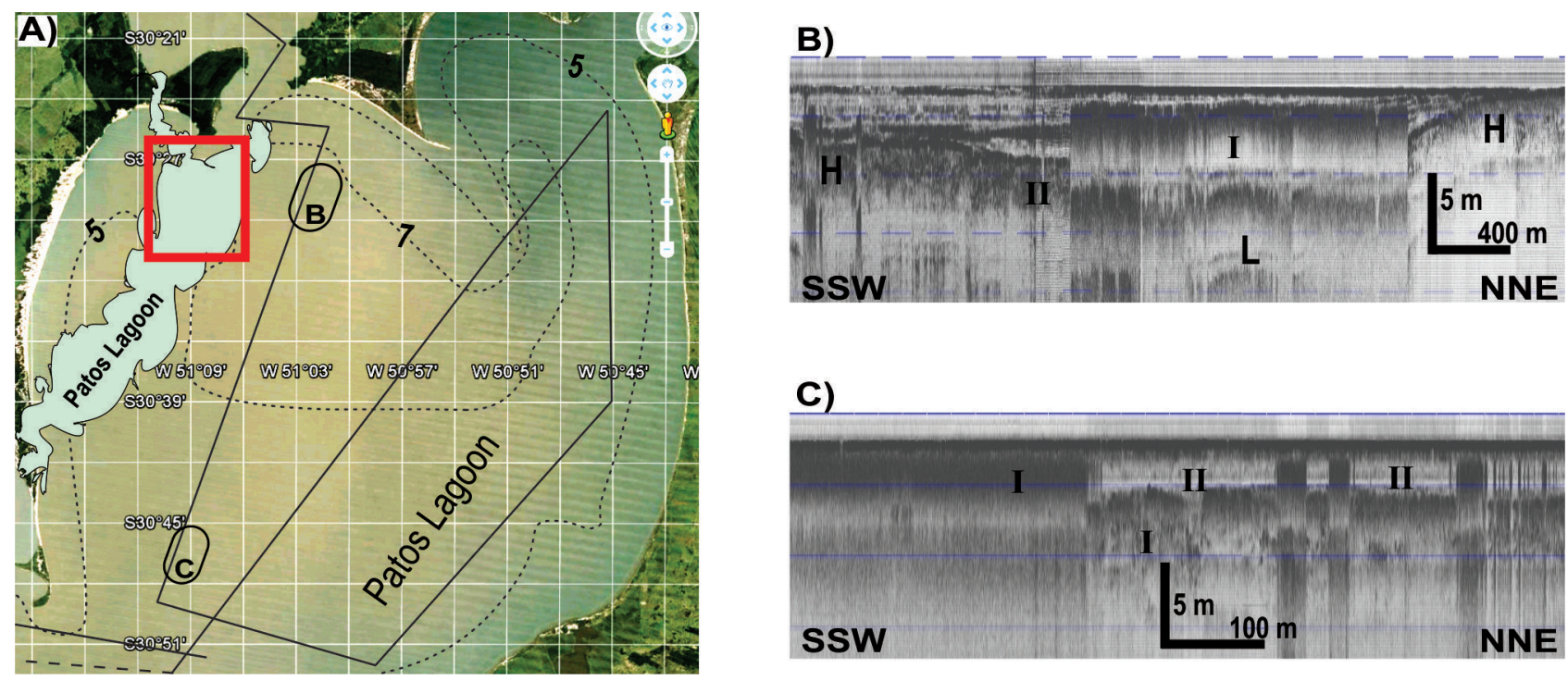

Figure 4. Gas-related acoustic anomalies in the northern Patos Lagoon. A) Position of 7 (dashed lines) and $3.5 \mathrm{kHz}$ seismic profiles in the GE image (box); B) Gas occurrences related to paleo-topographic lows (L- Low, H- High); C) Gas curtains (I) intercalated with acoustic windows and disseminated gas (II).

Figura 4. Anomalias acústicas relacionadas ao gás no setor norte da Lagoa dos Patos. A) Posição dos perfis sísmicos de 7 (tracejado) e 3,5 kHz na imagem GE (retângulo); B) Ocorrências de gás relacionadas aos paleo baixos topográficos (L-Baixo, $H$ - Alto); C) Cortinas de gás (I) intercaladas com janelas acústicas e gás disseminado (II).

tiples is the expression of the reverberation of the seismic energy from the gas-induced extra reflectivity of the upper interface.

Acoustic blanking and gas brightening anomalies can also be observed elsewhere in the records from the Patos Lagoon, with form characterized by a transparent or signal-starved domain in the seismic section; the result of the acoustic signal attenuation by gas in the sediments. A gradual transition between such gas features as well as gas-free zones occurs in some echograms. Typically, acoustic turbid zones are formed at the border of pocket gas, along the lagoon margins and in sandier sediments.

Also occurring in the seismic records, a strong reflector at around $12 \mathrm{~m}$ depth below water level is visualized in some parts of the lagoon, whose east sloping gradient (oceanwards) marks a strong impedance contrast between two seismodepositional units. The depth of such sequence boundary is variable, reaching up to $30 \mathrm{~m}$ inside paleotopographic lows of the former coastal fluvial system. The incision of this feature has been related to the Last Glacial Maximum sea level lowstand (see Weschenfelder et al., 2008, 2010, 2014).

\subsection{Gas features distribution in the Patos Lagoon}

The high resolution seismic records of the Patos Lagoon revealed anomalous acoustic features that have been attributed as typical for gassy sediments (Weschenfelder et al., 2006). Based on the described shallow gas features the distribution of the gassy sediments is presented in Figure 5. It encompasses all the gas features visualized in $\sim 1,000 \mathrm{~km}$ seismic profiles of 7 and $3.5 \mathrm{kHz}$, including gas in the form of curtain, disseminated, blanket and associated features and also those places with minor quantities of gas-related anomalies, which acoustic turbidity is hindering complete or partially the definition and mapping of the seismic architectural elements or in turn the seismic reflectors.

In general terms, gassy sediments in the lagoon are concentrated in the deeper and inner areas, where the bottom and shallow sub-bottom sediments are finer (silt and clay), as opposed to the sandy margins. According to Toldo Jr. (1994), the bottom sediments comprise marginal sands $(60 \%$ in area) and internal muddy sediments (up to $6 \mathrm{~m}$ thick), with water depths ranging between 5 and 6 $\mathrm{m}$ separating both areas. 


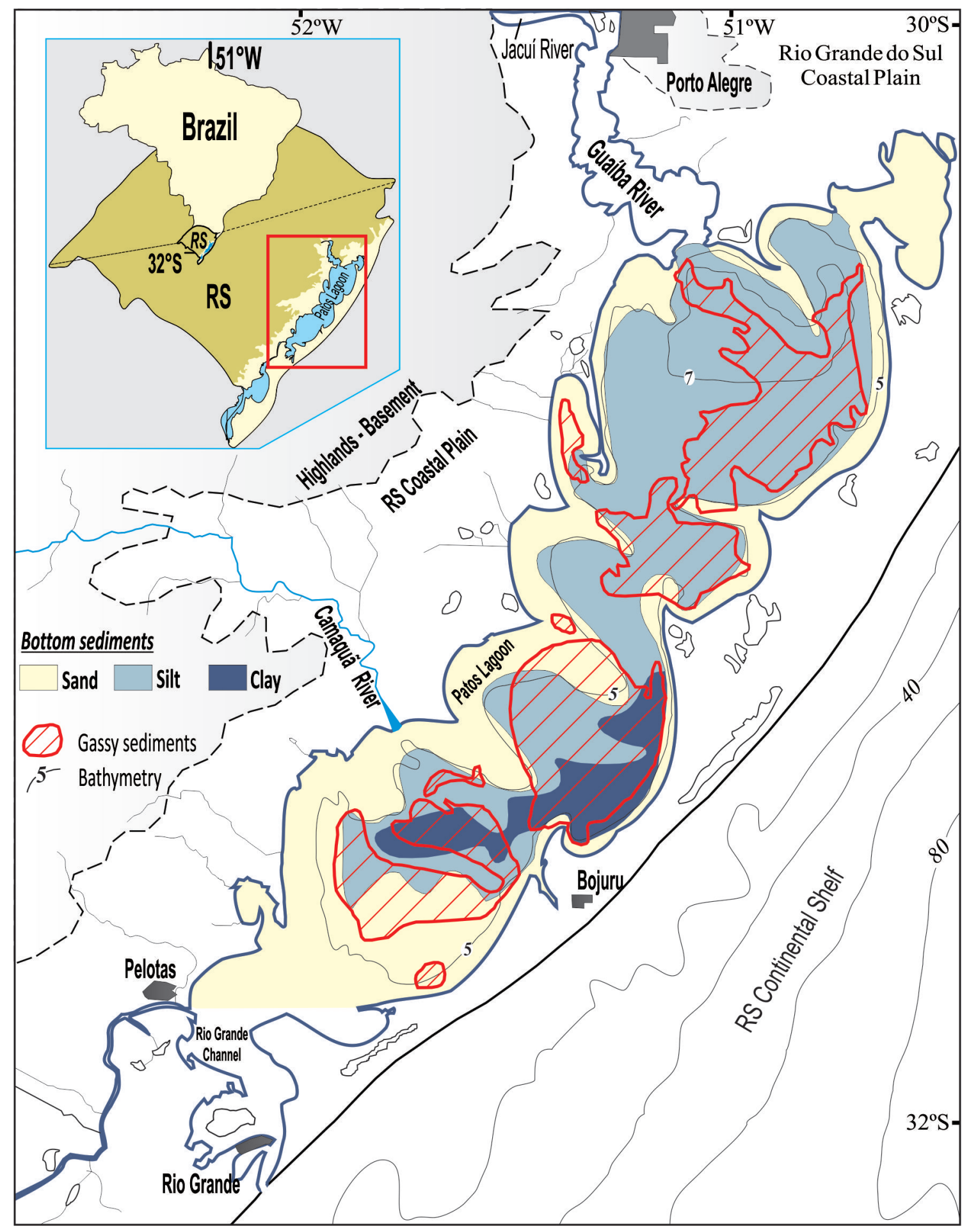

Figure 5. Distribution of gas-charged sediment (modified from Vasconcellos, 2009) and bottom sediment types (modified from Toldo Jr., 1994) in the Patos Lagoon.

Figura 5. Distribuição dos sedimentos com gás (modificado de Vasconcellos, 2009) e tipos de sedimentos de fundo (modificado de Toldo Jr., 1994) da Lagoa dos Patos. 


\section{Discussion}

The presence of gas disseminated in sediments plays an important role on the geoacoustic behavior of the bottom and sub-bottom environments been surveyed by seismo-acoustic tolls. The gas features are clearly identified in high frequency and resolution echograms as anomalous or chaotic seismic reflections, as seen in the various examples from the Patos Lagoon seismic records of figures 2, 3 and 4 .

Gas accumulation signature in seismic records have been described and classified by means of various terms. Different names for similar accumulations, and overlaps of names referring to the classification of different features occur. The terminology adopted here follows the synopsis of the various terms used to describe and classify gas accumulation in coastal environments presented by Weschenfelder et al. (2016). According to these authors, gas occurrences can be described and classified from the echo-character signatures observed in sub-bottom and side scan sonar records. They listed gas features, in a not exhaustive way, observed in echograms from selected coastal places and corresponding terminology. Gas curtain feature is a gas accumulation showing morphology in the form of a box of anomalous reflection. The upper surface is normally well marked by strong and relatively continuous reflectors, where acoustic response below them is usually chaotic and masking the underlying reflectors. In the acoustic blanking phenomenon, the reflector below the gassy horizon is very weak or absent due the sound wave attenuation (Judd \& Hovland, 1992; Orange et al., 2005). The top of the gas occurrence is very reflective, masking the underlying reflectors. Such phenomenon has been also referred to as blankets or acoustic masking (Garcia-Gil et al., 2002; Frazão \& Vital, 2007; Mazumdar et al., 2009). The acoustic turbid zone accumulation is characterized by more irregular and less pronounced top reflectors than gas curtain. The reflectors underlying the top of the gas accumulation are not completely hidden, allowing the visualization of the underneath sedimentary structures (Judd \& Hovland, 1992). Brightening sectors in the echogram caused by the increasing contrast of the acoustic speed be- tween zones with minor gas content and gas free are referred as gas brightening (Judd \& Hovland 1992; Hart \& Hamilton, 1993). The acoustic window in the echogram indicates an abrupt lateral change from gas-charged to gas-free sediments (Figueiredo Jr. et al., 1996; Costa \& Figueiredo Jr., 1998). The black shadow feature is characterized by several multiples of the gas surface masking the structure below it (Baltzer et al., 2005). A variation of the acoustic blanking, the turbidity pinnacle features as a downward concave U-shape obscuring any feature below it (Iglesias \& Garcia-Gil, 2007; Souza et al., 2011). Moreover, the terms for gas leaks and gas seeps were also described and referred by Weschenfelder et al. (2016) according to their echo-character signatures, which features are: acoustic plume, which feature appear as discrete hyperbolic curves in the water column due to free gas bubbles been exhausted into the water (Lee et al., 2005; Garcia-Gil et al., 2002; Diez et al., 2007; Duarte et al., 2007); the intra-sedimentary plume refers to parabolic reflectors cross-cutting real reflectors (Iglesias \& Garcia-Gil, 2007; Souza et al., 2011); and, the pockmark are crater-like features on the sediment-water interface caused by gases and liquids erupting and streaming through the sediments into the water column (Garcia-Gil et al., 2002; Iglesias \& Garcia-Gil, 2007).

In the echograms analyzed from the Patos Lagoon, sectors with gas curtains, acoustic turbid zones and other gas-related seismic signatures can be separated based on the characteristics of such acoustic anomalies. Besides, zones of acoustic anomalies intercalate with acoustic windows, meaning zones with gas alternating with others lacking or with very small amount of gas, respectively (Weschenfelder et al., 2006).

Some acoustic windows in the Patos Lagoon echograms are straightforward due to an abrupt lateral change in the echo character, which suggest either an absence of gas generating organic matter or the absence of trapping (Figueiredo Jr. et al., 1996; Costa \& Figueiredo Jr., 1998), the latter being most likely since there is no discernible change in the stratigraphic or architectural elements in the seismic record.

The main source of organic matter to the Patos Lagoon is the Guaíba system and, as a con- 
sequence, the concentration of particulate organic matter is higher in the northern lagoon area (Baisch \& Wasserman, 1998; Calliari et al., 2009). Autochthonous contribution can be also important to the total organic matter budget in the Patos Lagoon (Kjerve \& McKellar, 1980; Medeanic et al., 2007), but the quantification from the various sources is unknown.

The gas locations in the Patos Lagoon are related with the sedimentary distribution (Fig. 5). Either in curtains or acoustic turbid zones, the gassy sediments occur mostly in innermost lagoon areas, where the finer (silt and clay) bottom sediments occur, and also frequently associated with paleo-low terrains related to ancient coastal plain morphology and incised valleys systems as related by Weschenfelder et al. $(2006,2016)$. Such former drainage systems were active during the sea level lowering events, being than drowned and filled up by coastal sediments during the subsequent transgressions (Weschenfelder et al., 2014).

Shallow gas in sediments normally results from the biogenic degradation of organic matter ensnared in sediment (Kaplan, 1974). Much of the organic material in the coastal systems is introduced as flocculants (central basin) or from bayhead deltaic growth into the estuary (e.g. Zaitlin et al., 1994). Therefore, such gas accumulations seem intimately linked to the sedimentary environments and the evolution of the RS coastal zone. Areas of paleo-topographic lows and of former deltaic environments show the most important gas occurrences. These former topographic lows correspond to the paleo-course of rivers (e.g. Camaquã and Jacuí rivers) dissecting the RS coastal plain during sea level lowstands (Corrêa, 1996; Abreu \& Calliari, 2005; Corrêa et al., 2014), whose infilling package is then related to subsequent transgressive events (Weschenfelder et al., 2006, 2010, 2014).

A strong reflector at around $12 \mathrm{~m}$ depth below water level is visualized in most of the seismic profiles, whose east gradient sloping (oceanwards) is similar to that of the lagoon bottom. It marks a strong impedance contrast between two seismo-depositional units, whose occurrence has been related to a sequence boundary (Weschenfel- der et al., 2014) between the former coastal plain landscape and the Holocene lagoon sedimentation (Toldo Jr. et al., 2000, 2006). According to Toldo Jr. et al. (2006) the thickness of this Holocene unit is approximately $6 \mathrm{~m}$ in the center of lagoon, becoming progressively thinner and eventually disappearing towards the margin. Nevertheless recent papers indicate that occasionally this Holocene sedimentation unit reaches at least 30 m thick inside buried incised valleys (e.g. Camaquã and Jacuí incised valleys), which were infilled during the last transgression and highstand sea level periods (Weschenfelder et al., 2014, 2016; Santos-Fischer et al., 2016).

The shallow gas documented here are commonly associated with the trapping of fine-grained sediments following transgressive infilling of paleo-lows and establishment of the lagoon system in a predominantly low energy setting. The lagoon can be considered a sink for fine-grained organic material transported through the Jacuí and Camaquã fluvial systems. Despite the evidence of compound incised valleys in the RS coastal plain, the gas is associated with the youngest post Last Glacial Maximum-aged infill packages (Weschenfelder et al., 2014). The gassy deposits related here resemble the central basin zone for the incised valley models of Zaitlin et al. (1994), an area marked by accumulation of muddy floccules and organic-rich detritus. The gas source and accumulation mode reflects the sedimentary environments and evolutionary processes responsible for the lagoon formation. Its location in a tropical to subtropical climate favors high productivity in terms of organic matter (Weschenfelder et al., 2016).

The study of the various gas-related features from the Patos Lagoon may provide some significant clues for the modeling of the geological evolution of coastal environments. It is valid mainly for the Pleistocene and Holocene, periods recognized worldwide as marked by significant shifts in coastal depositional system triggered by oscillating sea levels. Gassy sediments are usually associated to transgressive infilling of low-lying, paleo-coastal plain topography. This assumption may be important in helping to interpret the evolution of various sub-tropical and tropical coastlines where gas is commonly found obscuring the seismic records. 


\section{Conclusion}

Gas-charged sediments occur commonly across the Patos Lagoon interior, and their presence has a significant effect on the geoacoustic behavior of the lagoon bottom and sub-bottom sediments when surveying with seismoacoustic tolls. The gas-related features can be clearly visualized as acoustic anomalies detected as anomalous seismic reflections in the high frequency and resolution echograms. Such acoustic anomalies show distinctive morphology for sediment-trapped gas, leaking gas or free gas in the water column. The gas-related echo-character signatures observed in echograms from the Patos Lagoon can be described and classified by means of various terms, like the most common gas curtain, acoustic blanking, acoustic turbid zone, gas brightening, acoustic window, black shadow, turbidity pinnacle and plumes. These features are also commonly observed in most of the coastal environments worldwide. The gas accumulations in the Patos Lagoon occur in dominantly fine-grained sediments of the inner basin deposits and in sediments infilling incised valley systems. The gas is derived from the settling of organic-rich material in the inner basin of the lagoon and locals hosting former incised valley systems. The gas is relatively young and is associated with the most recent postglacial transgressive infilling period of the lagoon basin and associated fluvial incisions. Some paleo-topographic lows, filled with gas-charged sediments, are related to fluvial incision developed due sea level up and downs of the Pleistocene period. Therefore, some of the shallow gas occurrences in the RS coast seem to be controlled by the previous environmental configuration, the transgressive infilling arrangement of the basin, and the hydrodynamic conditions. Since the establishment of the present coastal configuration, following sea level highstand of the Holocene, the Patos Lagoon became a coastal trap for gas-generator sediments.

Acknowledgments. The research has been supported by CNPq (141975/2011-3, 300609/20132, 301668/2017-5) and CAPES (Ciências do Mar II - 23038.004306/2014-17).

\section{References}

Abreu, J.G. \& Calliari, L.J. 2005. Paleocanais da plataforma continental interna do Rio Grande do Sul: evidências de uma drenagem fluvial pretérita. Revista Brasileira de Geofísica, 23(2): 123132.

Aliotta, S., Spagnuolo, J.O. \& Farinati, E. 2009. Origen de una roca de playa en la región costera de Bahía Blanca, Argentina. Pesquisas em Geociências, 36(1): 107-116.

Aliotta, S., Ginsberg, S.S., Giagante, D., Vecchi, L.G. \& Salvatierra, M.M. 2014. Seismic Stratigraphy of Pleistocene Deltaic Deposits in Bahía Blanca Estuary, Argentina. Anais da Academia Brasileira de Ciências, 86(2): 649-662.

Andrade Neto, J.S., Rigon, L.T., Toldo Jr., E.E. \& Schettini, C.A.F. 2012. Descarga sólida em suspensão do sistema fluvial do Guaíba, RS, e sua variabilidade temporal. Pesquisas em Geociências, 39(2): 161-171.

Baisch, P.R. \& Wasserman, J.C. 1998. Chemistry and distribution of trace elements in the Patos Lagoon, South Brazil. In: Wasserman, J., Silva-Filho, E.V. \& Villas-Boas, R. (Eds.), Environmental Geochemistry in the Tropics. Lecture Notes in Earth Sciences, 72: 97-126.

Baltzer, A., Tessier B., Nouzé, H., Bates, R., Moore, C. \& Menier, D. 2005. Seistec Seismic Profiles: a Tool to Differentiate Gas Signatures. Marine Geophysical Researches, 26(2/4): 235-245.

Baptista Neto, J.A, Silva, M.A.M. \& Figueiredo Jr., A.G. 1996. Sísmica de alta frequência e o padrão de distribuição de sedimentos na Enseada de Jurujuba (Baía de Guanabara) - RJ/Brasil. Revista Brasileira de Geofísica, 14(1): 51-57.

Baptista Neto, J.A., Silva, C.G., Dias, G.T.M. \& Fonseca, E.M. 2011. Distribuição sedimentar da Lagoa Rodrigo de Freitas através de sísmica de alta resolução. Revista Brasileira de Geofísica, 29(1): 187-195.

Calliari, L.J., Winterwerp, J.C., Fernandes, E., Cuchiara, D., Vinzon, S.B., Sperle, M. \& Holland, K.T. 2009. Fine grain sediment transport and deposition in the Patos Lagoon-Cassino beach sedimentary system. Continental Shelf Research, 29: 515-529. 
Catanzaro, L.F., Baptista Neto, J.A., Guimarães, M.S.D. \& Silva, C.G.I. 2004. Distinctive sedimentary processes in Guanabara Bay - SE/Brazil, based on the analysis of echo-character (7.0 $\mathrm{kHz}$ ). Revista Brasileira de Geofísica, 22(1): 6983.

Corrêa, I.C.S. 1996. Les variations du niveaux de lamer Durant lês derniers 17.500 ans BP: l'example de la plate-forme continentale du Rio Grande do Sul-Brasil. Marine Geology, 130: 163-178.

Corrêa, I.C.S., Toldo Jr., E.E., Weschenfelder, J., Baitelli, R., Ayup-Zouain, R.N., Dehnhardt, B.A. \& Martins, L.R.S. 2007. Plataforma e Talude Continental do Rio Grande do Sul: síntese dos conhecimentos. In: Iannuzzi, R. \& Frantz, J.C. (Eds.), 50 anos de Geologia: IGEO/UFRGS, Porto Alegre, p. 341-353.

Corrêa, I.C.S., Medeanic, S., Weschenfelder, J., Toldo Jr., E.E., Nunes, J.C. \& Baitelli, R. 2014. The paleodrainage of the La Plata River in southern Brazil Continental Shelf. Revista Brasileira de Geofísica, 32(2): 259-271.

Costa, E.A. \& Figueiredo Jr., A.G. 1998. Echo-Character and Sedimentary Processes on the Amazon Continental Shelf. Anais da Academia Brasileira de Ciências, 70(2): 87-200.

Diez, R., García-Gil, S., Durán, R. \& Vilas, F. 2007. Gas accumulations and their association with particle size distribution patterns in the Ría de Arousa seabed (Galicia, NW Spain) an application of discriminant analysis, Geo-Marine Letters, 27(2/4): 89-102.

Duarte, H., Pinheiro, L.M., Teixeira, F.C. \& Monteiro, J.H. 2007. High-resolution seismic imaging of gas accumulations and seepage in the sediments of the Ria de Aveiro barrier lagoon (Portugal). Geo-Marine Letters, 27(2/4): 15-126.

Emeis, K.C., Brüchert, V., Currie, B., Endler, R., Ferdelman, T., Kiessling, A., Leipe, T., Noli-Peard, K., Struck, U. \& Vogt, T. 2004. Shallow gas in shelf sediments of the Namibian coastal upwelling ecosystem. Continental Shelf Research, 24(6): 627-642.

Figueiredo Jr., A.G., Nittrouer, C.A. \& Costa, E.A. 1996. Gas-charged sediments in the Amazon Submarine Delta. Geo-Marine Letters, 16: 31-35.

Frazão, E. \& Vital, H. 2007. Estruturas rasas de gás em sedimentos no estuário Potengi (Nordeste do Brasil). Revista Brasileira de Geofísica, 25(1): 17-26.

Garcia-Gil, S., Vilas, F. \& Garcia-Garcia, A. 2002. Shallow gas features in incised-valley fills (Ría de Vigo, NW Spain): a case study. Continental Shelf Research, 22: 2303-2315.

Hart, B.S. \& Hamilton, T.S. 1993. High resolution acoustic mapping of shallow gas in unconsolidated sediments beneath the Strait of Georgia, British Columbia. Geo-Marine Letters, 13: 4955.

Iglesias, J. \& García-Gil, S. 2007. High-resolution mapping of shallow gas accumulations and gas seeps in San Simón Bay (Ría de Vigo, NW Spain). Some quantitative data. Geo-Marine Letters, 27(2/4): 103-114.

Jensen, J.B. \& Bennike, 0. 2009. Geological setting as background for methane distribution in Holocene mud deposits, Arhus Bay, Denmark. Continental Shelf Research, 29(5/6): 775-784.

Jones, E.J.W. 1999. Marine Geophysics. Chichester, England, John Wiley \& Sons Ltd, 466 p.

Judd, A.G. 2004. Natural seabed gas seeps as sources of atmospheric methane. Environmental Geology, 46: 988-996.

Judd, A.G. \& Hovland, M. 1992. The evidence of shallow gas in marine sediments. Continental Shelf Research, 12(10): 1081-1095.

Kaplan, I.R. 1974. Introduction. In: Kaplan, I.R. (Ed.) Natural gases in Marine Sediments. New York, Planum Press, p. 1-10.

Kjerfve, B. \& McKellar Jr., H.N. 1980. Time series measurements of estuarine material fluxes. In: Kennedy, V.S. (Ed.). Estuarine Perspectives. New York, Academic Press, p. 341-357.

Klein, A.H.F., Demarco, L.F.W., Guesser, V., Flemming, G.R., Bonetti, J., Porpilho, D., Ayres Neto, A., Souza, J.A.G. \& Félix, C.A. 2016. Shallow gas seismic structures: forms and distribution on Santa Catarina Island, Southern Brazil. Brazilian Journal of Oceanography, 64(4): 325-338.

Lafferty, B., Quinn, R. \& Breen, C. 2006. A side-scan sonar and high-resolution CHIRP sub-bottom profile study of the natural and anthropogenic sedimentary record of Lower Lough Erne, northwestern Ireland. Journal of Archaeological Science, 33: 756-766.

Lee, G.H., Kim, D.C., Kim, H.J., Jou, H.T. \& Lee, Y.J. 
2005. Shallow gas in the central part of the Korea Strait shelf mud off the southeastern coast of Korea. Continental Shelf Research, 25(16): 2036-2052.

Marino, I.K., Santos, M.A.C. \& Silva, C.G. 2013. Processing the high-resolution, shallow seismic profiles, Guanabara bay - Rio de Janeiro State, Brazil. Revista Brasileira de Geofísica, 31(4): 579-594.

Marques, W.C. 2005. Padrões de variabilidade temporal nas forçantes da circulação e seus efeitos na dinâmica da Lagoa dos Patos, Brasil. Rio Grande, 87p. Dissertação de Mestrado, Programa de Pós-Graduação em Oceanografia Física, Química e Geológica, Instituto de Oceanografia, Universidade Federal de Rio Grande.

Marques, W.C. 2012. The temporal variability of the freshwater discharge and water levels at the Patos Lagoon, Brazil. International Journal of Geosciences, 3: 758-766.

Marques, W.C. \& Möller, 0.0. 2008. Variabilidade temporal em longo período da descarga fluvial e níveis de água da Lagoa dos Patos, Rio Grande do Sul, Brasil. Revista Brasileira de Recursos Hídricos, 13(3): 155-163.

Mazumdar, A., Peketi, A., Dewangan, P., Badesab, F., Ramprasad, T., Ramana, M.V., Patil, D.J. \& Daya, A. 2009. Shallow gas charged sediments off the Indian west coast: Genesis and distribution. Marine Geology, 267(1/2): 71-85.

Medeanic, S., Corrêa, I.C.S. \& Weschenfelder, J. 2007. Palinomorfos nos sedimentos de fundo da laguna dos Patos-RS: Aplicação nas reconstruções paleoambientais. Gravel, 5: 89-102.

Mitchum Jr., R.M., Vail, P.R. \& Sangree, J.B. 1977. Seismic stratigraphy and global changes of sea level, part 6: stratigraphic interpretation of seismic reflection patterns in depositional sequences. In: Payton, C.E. (Ed.), Seismic Stratigraphy e Applications to Hydrocarbon Exploration. American Association of Petroleum Geologists Memoir 26: 117-133.

Orange, D., García-García, A., Lorenson, T., Nittrouer, C., Milligan, T., Miserocchi, S., Langone, L., Correggiari, A. \& Trincardi, F. 2005. Shallow gas and flood deposition on the Po Delta. Marine Geology, 222/223: 159-177.

Pinet, N., Duchesne, M., Lavoie, D., Bolduc, A. \&
Long, B. 2008. Surface and subsurface signatures of gas seepage in the St. Lawrence Estuary (Canada): Significance to hydrocarbon exploration. Marine Petroleum Geology, 25: 271-288.

Premchitt, J., Rad, N.S., To, P., Shaw, R. \& James, J.W.C. 1992. A Study of Gas in Marine Sediments in Hong Kong. Continental Shelf Research, 12(10): 1251-1264.

Quaresma, V.S., Dias, G.T.M. \& Baptista Neto, J.A. 2000. Caracterização da ocorrência de padrões de sonar de varredura lateral e sísmica de alta frequência (3,5 e 7,0 kHz) na porção sul da Baía de Guanabara-RJ. Revista Brasileira de Geofísica, 18(2): 201-214.

Santos-Fischer, C.B., Corrêa, I.C.S., Weschenfelder, J., Torgan, L.C. \& Stone, J.R. 2016. Paleoenvironmental insights into the Quaternary evolution of the southern Brazilian coast based on fossil and modern diatom assemblages. Palaeogeography, Palaeoclimatology, Palaeoecology, 446: 108-124.

Souza, J. de, Tessler, T., Félix, C., Franklin, L., Benedet, L., Suthard, B., Demarco, L.F.W., Bonetti, J. \& Klein, A.H.F. 2011. Gas features detected with ultra shallow water high resolution seismic in the North Bay, Santa Catarina state, Southern Brazil. In: CONGRESSO LATINO-AMERICANO DE CIÊNCIAS DO MAR, 14., 2011, Balneário Camboriú-SC. Anais...Balneário Camboriú, AOCEANO.

Terra, L.C., Calliari, L.J. \& Griep, G.H. 2014. Acumulações de gás nos sedimentos da plataforma continental interna do Rio Grande do Sul. In: SIMPÓSIO BRASILEIRO DE GEOFÍSICA, 6., 2014, Porto Alegre-RS. Anais... 3p.

Toldo Jr., E.E. 1994. Sedimentação, predição do padrão de ondas e dinâmica sedimentar da antepraia e zona de surfe do sistema lagunar da Lagoa dos Patos, RS. Porto Alegre, 189p. Tese de Doutorado, Programa de Pós-Graduação em Geociências, Instituto de Geociências, Universidade Federal do Rio Grande do Sul.

Toldo Jr., E.E., Dillenburg, S.R., Corrêa, I.C.S. \& Almeida, L.E.S.B. 2000. Holocene sedimentation in Lagoa dos Patos Lagoon, Rio Grande do Sul, Brazil. Journal of Coastal Research, 16(3): 816822.

Toldo Jr., E.E., Dillenburg, S.R., Corrêa, I.C.S., Almei- 
da, L.E.S.B., Weschenfelder, J. \& Gruber, N.L.S. 2006. Sedimentação de longo e curto período na Lagoa dos Patos, Sul do Brasil. Pesquisas em Geociências, 33(2): 79-86.

Tomazelli, L.J. \& Villwock, J.A. 2000. O Cenozóico no Rio Grande do Sul: Geologia da Planície Costeira. In: Holz, M. \& De Ros, L.F. (Eds.). Geologia do Rio Grande do Sul. Porto Alegre, CIGO/UFRGS, p. 375-406.

Vasconcellos, V.E.B. 2009. Mapeamento e caracterização das acumulações de gás raso na Lagoa dos Patos, Sul do Brasil-RS. Porto Alegre, 117p. Dissertação de Mestrado, Programa de Pós-Graduação em Geociências, Instituto de Geociências, Universidade Federal do Rio Grande do Sul.

Vaz, A.C., Möller Jr., O.O. \& Almeida, T.L.D. 2006. Análise quantitativa da descarga dos rios afluentes da Lagoa dos Patos. Atlântica, 28: 13-23.

Villwock, J.A. \& Tomazelli, L.J. 1995. Geologia Costeira do Rio Grande do Sul. Notas Técnicas, 8: $1-45$.

Weschenfelder, J., Corrêa, I.C.S., Aliotta, S., Pereira, C.M. \& Vasconcellos, V.E.B., 2006. Shallow gas accumulation in sediments of the Patos Lagoon, Southern Brazil. Anais da Academia Brasileira de Ciências, 78(3): 607-614.

Weschenfelder, J., Medeanic, S., Corrêa, I.C.S. \& Aliotta, S. 2008. Holocene paleoinlet of the Bojuru region, Lagoa dos Patos, southern Brazil. Journal of Coastal Research, 24(1): 99-109.

Weschenfelder, J., Corrêa, I.C.S., Aliotta, S. \& Baitelli, R. 2010. Paleochannels related to late Quaternary sea-level changes in southern Brazil. Brazilian Journal of Oceanography, 58: 35-44.

Weschenfelder, J., Baitelli, R., Corrêa, I.C.S., Bortolin, E.C. \& Santos, C.B. 2014. Quaternary incised valleys in the southern Brazil coastal zone. Journal of South American Earth Science, 55: 83-93.
Weschenfelder, J., Klein, A.H.F., Green, A.N., Aliotta, S., Mahiques, M.M., Ayres Neto, A., Terra, L.C., Corrêa, I.C.S., Calliari, L.J., Montoya, I., Ginsberg, S.S. \& Griep, G.H. 2016. The control of palaeotopography in the preservation of shallow gas accumulation: Examples from Brazil, Argentina and South Africa. Estuarine, Coastal and Shelf Science, 172: 93-107.

Zaitlin, B.A., Dalrymple, R.W. \& Boyd, R. 1994. The stratigraphic organization of incised valley systems associated with relative sea-level change. In: Dalrymple, R.W., Boyd, R.J. \& Zaitlin, B.A. (Eds.). Incised valley systems: Origin and sedimentary Sequences, SEPM Spec. Pub. 51: 45-60.

Manuscrito 683 | Recebido em maio de 2017 | Aceito em dezembro de 2018| Editora: Maria L. C. da C. Rosa 